\title{
The sympathetic plot, its psychological origins, and implications for the evolution of fiction
}

\author{
Manvir Singh \\ Institute for Advanced Study in Toulouse \\ manvir.manvir@gmail.com
}

\begin{abstract}
The sympathetic plot-featuring a goal-directed protagonist who confronts obstacles, overcomes them, and wins rewards-is ubiquitous. Here, I propose that it recurs because it entertains, engaging two sets of psychological mechanisms. First, it triggers mechanisms for learning about obstacles and how to overcome them. It builds interest by confronting a protagonist with a problem and induces satisfaction when the problem is solved. Second, it evokes sympathetic joy. It establishes the protagonist as an ideal cooperative partner pursuing a goal, appealing to mechanisms for helping. When the protagonist succeeds, they receive rewards, and audiences feel sympathetic joy, an emotion normally triggered when beneficiaries triumph. The capacities underlying the sympathetic plot evolved for learning and cooperation before being co-opted for entertainment.
\end{abstract}

Keywords: empathy, evolution, fiction, pleasure, sympathy, universals 


\section{The sympathetic plot}

Once upon a time, a strong, attractive hero lost one or both of his parents. He then overcame a series of obstacles and faced off against a monster that had terrorized his community. The hero vanquished the monster and was celebrated.

This is the story of Harry Potter, Superman, James Bond, Luke Skywalker, and The Lion King's Simba. It's the story of the Sotho hero Litaolane (Lesotho: Casalis, 1861, pp. 347-350), the Garo hero Jereng (India: Rongmuthu, 1960), the Ainu mythological hero Yayresu:po (Northeast Asia: Ohnuki-Tierney, 1974), and the heroic twins Kototabe and Kelokelo of New Guinean folklore (Ker, 1910, pp. 61-63). If the hero is a youngest-born sibling rather than an orphan, this becomes the story of the ancient Greek god Zeus (in his confrontation with Kronos: Hard, 2004, pp. 67-69), the ancient Chinese heroine Li Chi (Kao, 1985, pp. 105-106), and the princely main character of the Serbian tale Baš Čelik (Petrovitch, 1915, pp. 247-267).

Here's another story:

Once upon a time, a poor girl lived with her abusive stepsiblings or stepparents. She embarked on a journey, received gifts from a big-hearted helper, and eventually escaped her destitution. Her terrorizers, jealous of her success, were punished.

This is the story of Cinderella (Perrault, 1697). Similar tales have been told across Europe (Cox, 1893), as well as in Burma (Lwin, 2010, pp. 39-42), Hausaland (West Africa: Alidou, 2002), Japan (Whitehouse, 1935), and the Malay world (Donaldson, 2014), among many other places (Dundes, 1982). If the story features a little boy rather than a little girl, this becomes the Himalayan "Story of the Black Cow" (Dracott, 1906, pp. 83-87); if the heroine is tormented by older blood-siblings rather than step-siblings, this becomes the tale of the girl with a marred face, told by peoples throughout northeastern North America (e.g., Mi'kmaq: Olcott, 1917, pp. 17-22; Algonquian: Rafe, 1992; Ojibwe: San Souci, 1994).

The orphaned monster-slayer and the Cinderella story are both examples of what I term the sympathetic plot. ${ }^{1}$ The sympathetic plot is a ubiquitous and popular narrative structure defined here on the basis of five core features:

1. A protagonist, sometimes referred to as a hero or heroine, has a goal.

2. The protagonist's goal is relatable or justifiable, like marrying a prince, escaping poverty, killing a monster, or procuring a magical item.

\footnotetext{
${ }^{1}$ In this paper, I refer to the sympathetic plot, sympathetic joy, and sympathetic characters. By sympathetic plot, I mean stories featuring a goal-directed protagonist who confronts an obstacle, overcomes it, and reaps rewards. By sympathetic joy, I mean the pleasure we experience at another person's good fortune. By sympathetic characters, I mean characters whom audiences like, feel for, and want to help. I use sympathetic in all three contexts partly because of precedent (at least for joy and character) and partly because theoretical reasons justify a common term. As I argue, the sympathetic plot seems partly designed to engender audience sympathy towards protagonists (i.e., audiences feel for protagonists and want to help them; see Table 1 in Goetz et al., 2010 for definitions of sympathy). When the character succeeds, audiences experience sympathetic joy.
} 
3. The protagonist confronts an obstacle in pursuit of their goal, sometimes in the form of mean opponents.

4. The protagonist prevails. This might be due to their own virtue or outside assistance.

5. The protagonist reaps rewards. These can include wealth, power, an attractive spouse, new parents who are loving and kind, or a boon that they bestow on humanity.

Stories with these core features, referred to here as sympathetic tales, frequently exhibit at least six secondary features, as well. These elements do not appear in all sympathetic tales, but they are common:

6. The protagonist is appealing. They might be strong, clever, humble, skillful, attractive, generous, or considerate.

7. The protagonist is alone and suffers early misfortunes. They might be orphaned, abandoned, or the child of poor rural-folk.

8. The protagonist is high-status, or at least tied to high-status individuals. They might be orphaned but then adopted by royalty. They might be abandoned but also the offspring of deities. They might be the child of poor rural-folk but known throughout the land because of prophecies about them.

9. The protagonist journeys to distant places to achieve their goals. On the way, they encounter foreign and fantastical obstacles.

10. The protagonist's opponents are repulsive and formidable. They might be dragons, callous step-sisters, or pompous rival princes.

11. Characters who oppose the protagonist eventually suffer or are reformed.

The sympathetic plot has been recognized by folklorists and mythologists for the last 150 years, although nearly all scholars organized these features within more elaborate templates. Von Hahn (1876), Rank (1914), and Raglan (1936) documented the sympathetic plot in their studies of mythical heroes from Europe, West Asia, and the Middle East (see also Cook, 1965). Propp (1968, pp. 50, 92) uncovered it in his study of Russian folktales. Thompson (1946, p. 23) saw it in complex Eurasian fairy tales; Kimball (1999) described it in her cross-cultural study of orphan tales; and Carroll, Gottschall, Johnson, and Kruger (2012, p. 26) noticed it in nineteenth-century British novels. When Jobling (2001) compared hero-ogre stories from around the world, he focused on elements such as the virtuousness of heroes and the repulsiveness of monsters, but underlying these parallels was the sympathetic structure.

Perhaps the best known hypotheses of universal narrative structure are those by Campbell (1949), Booker (2004), and Hogan (2003; 2011). All three provide further evidence for the sympathetic plot's ubiquity.

Campbell (1949) claimed that stories everywhere recount adventurous rites of passage. His template was complex, involving 17 events organized into three main stages, but he summarized the basic pattern as follows:

A hero ventures forth from the world of common day into a region of supernatural wonder: fabulous forces are there encountered and a decisive victory is won: the hero comes back from this mysterious adventure with the power to bestow boons on his fellow man. (Campbell, 1949, pp. 30) 
Starring a protagonist who overcomes obstacles, achieves a goal, and enjoys rewards, Campbell's hero's journey is a version of the sympathetic plot.

Booker (2004) reviewed 450 (mostly European and American) stories, spanning films, plays, novels, novellas, ancient epics, and fairy tales. He then organized those stories into seven plots: (1) Overcoming the Monster; (2) Rags to Riches; (3) The Quest; (4) Voyage and Return; (5) Comedy (defined broadly to include many romantic stories); (6) Tragedy; and (7) Rebirth.

Six of Booker's plots-all except Tragedy-are sympathetic plots. They tell of goaldirected protagonists who confront obstacles, overcome them, and enjoy prizes. In fact, they differ almost solely on what the protagonist's goal is, whether it be destroying a monster, overcoming hardship, procuring a priceless object, returning home, finding love, or escaping a dark spell. Booker's plots also exhibit many of the secondary features listed earlier. Some protagonists start out in distressing circumstances, some are honorable and strong, some face off against terrible opponents, and some go off on far-away journeys.

Finally, there are the patterns proposed by Hogan (2003). Hogan read pre-colonial literature from every inhabited continent and suggested three universals: romantic, heroic, and sacrificial. Romantic and heroic stories often have sympathetic plots. In romantic stories, two people fall in love, although forces prevent their union. Eventually, they are united. In heroic stories, a legitimate leader's position is usurped. The usurped leader vanquishes an out-group enemy, re-establishing their authority. Crucially, Hogan pointed out, both plots can be truncated, turning them into tragedies and violating the sympathetic structure.

Hogan's (2003) third narrative universal is less clearly a sympathetic plot. In sacrificial stories- " "perhaps the least obviously prototypical" (Hogan, 2011, p. 133) — a deity punishes a society's sins, most often with famine. The society responds by sacrificing an innocent person, leading to restoration and agricultural abundance. Systematic cross-cultural research will confirm whether sacrificial stories are ubiquitous. Regardless, their existence underscores that sympathetic tales, while ubiquitous, do not exhaustively cover all stories (see also trickster stories and origin myths: Long, 2005; Scheub, 2007).

Why do people everywhere tell stories with such similar features? Here, I argue that the sympathetic plot recurs because it is a technology for producing pleasure. It develops from a cultural selection for entertainment and works by triggering two sets of psychological mechanisms:

1. It appeals to mechanisms involved in learning about obstacles and how to overcome them. It describes a character trying to solve a problem, building interest, narrowing attention, and eventually delivering satisfaction.

2. It appeals to mechanisms involved in allocating cooperative effort, evoking sympathetic joy. The protagonist appears as an ideal cooperative partner-competent, warm, and inneed-and they pursue a daunting goal. When they succeed, they receive rewards, and the audience feels sympathetic joy. Sympathetic joy usually occurs when a cooperative partner succeeds, and it likely exists to proximately motivate helping. Given the audience's attachment to the protagonist, however, the mechanism misfires, and they feel their fictive friend's fortune. 
Of course, this doesn't deny that other psychological mechanisms contribute to literary experiences. Stories may stir up past emotions (Hogan, 1996). They may engross through dazzling imagery and captivate through sex, threat, and coalitional conflict (Green \& Brock, 2000; Nettle, 2005; Stubbersfield et al., 2015). But these and other studied mechanisms (e.g., Mar, Oatley, Djikic, \& Mullin, 2011) are unimportant for explaining the sympathetic plot. Instead, I claim, the sympathetic plot recurs because it triggers systems adapted for learning about obstacles and allocating cooperative investment.

In the following sections, I (1) review existing explanations for the sympathetic plot; (2) propose that the sympathetic plot culturally evolves to entertain; (3) review how it entertains; and (4) use the account to explain core features of stories. I conclude with a list of 5 testable predictions.

\section{Existing approaches cannot explain the sympathetic plot}

Many writers have connected narrative patterns to human psychology (Bastian, 2005; Dundes, 1987; Hogan, 2003; Jung, 1959; Lévi-Strauss, 1955). As Witzel (2012, p. 12) wrote, many scholars "assume that similarities found in myths the world over are due to common, universal features of the human mind that forever produce the same images or "archetypes".

Despite this growing consensus, most major theories explaining versions of the sympathetic plot hinge on spurious or untested assumptions about the mind (Dutton, 2005). Rank (1914) interpreted the heroic legend as expressing sublimated Oedipal urges. Campbell (1949) saw hero's journey myths as conveyors of wisdom that arouse the psyche and provide understanding. Booker (2004) concluded that his seven basic plots were the unconscious's way of reminding the conscious self how to achieve a full life. The failure to ground these explanations in contemporary psychological science is striking given progress in the study of story (Bower \& Morrow, 1990; Gerrig, 1998; Oatley, 2011; Tan, 1996; Zillmann \& Vorderer, 2000), as well as the emergence of fields like literary Darwinism (Boyd 2009; Carroll 2011; Gottschall and Wilson 2005) and cognitive literary studies (Keen, 2007; Zunshine, 2006).

An important exception to this disconnect is Hogan's recent analysis. Across several works (e.g., Hogan 2003, 2011, 2017), Hogan has proposed a set of narrative universals (reviewed above) and applied insights from cognitive science to explain them.

Hogan's account is based on three premises. First, pursuing a goal is enjoyable. Second, people everywhere share goals, including having sex, achieving in-group prestige, and enjoying food and security. Third, stories produce emotional responses by activating remembered emotions and through empathically experiencing the character's emotions. Thus, he argues, stories in which protagonists pursue basic goals will produce pleasure across diverse audiences. His proposed universals reflect these shared goals. Romantic stories recur because the protagonist pursues sex and affiliation. Heroic stories recur because the protagonist pursues prestige and superiority over out-groups. And sacrifice stories recur because characters pursue food and security. Prototypes are universal, he maintains, because hearing about someone pursuing a familiar desire feels good.

Hogan's account establishes an ambitious baseline for scholars interested in explaining narrative patterns. Nevertheless, it suffers from at least two limitations. First, it was developed to explain his three universal prototypes, but as currently formulated, it fails to explain features of the sympathetic plot more generally, such as why protagonists often start out abandoned or why 
they are connected to high status. Second, Hogan's account focuses on empathy and remembered emotions, but as many researchers have demonstrated, our emotional responses to stories vary according to characters' traits (Raney, 2003). Coarsely, we feel good when a liked character succeeds and bad when they fail (Trabasso \& Chung, 2004; Zillmann \& Cantor, 1977). Moreover, we seem to represent characters, at least partly, as other people. We miss them, detest them, feel embarrassed for them, cry at their triumphs, and yell instructions at them, like "Run for it!" or "Close the door, stay in there!" (Bezdek et al., 2013; Hoffner \& Cantor, 1991). These observations do not invalidate Hogan's account, but they suggest an alternative hypothesis that centers on how we represent and respond to characters.

Another set of hypotheses that fail to explain the sympathetic plot are the simulation hypotheses. Although simulation hypotheses were not developed to explain the sympathetic plot, they are among the most prominent theories for the evolution and function of fiction.

Simulation hypotheses argue that stories, like flight simulators, instruct through simulation (Oatley, 2008). Oatley and Mar, for example, hypothesized two functions of fictional stories: (1) They develop abstract models of the social world, and (2) they encourage simulation of these models, developing empathy and theory of mind abilities (Mar \& Oatley, 2008; Oatley, 1999, 2016; Oatley \& Mar, 2005). Hobbs (1990) and then Pinker (1997, 2007), meanwhile, argued that fiction is less about abstract models or empathy and more about testing out strategies (see also Clasen, Kjeldgaard-Christiansen, \& Johnson, 2020; Morin, Acerbi, \& Sobchuk, 2019). Stories, they hypothesized, serve as thought experiments for solving problems. A storyteller identifies a goal, such as securing a romantic partner, and then tries out ways of achieving it under controlled settings. Gottschall (2012) integrated Hobbs's and Oatley's frameworks, equating fiction with play. According to his hypothesis, stories force audiences to experience protagonists' struggles, building implicit memories that prove useful in similar circumstances (see also Steen \& Owens, 2001). All of these hypotheses agree that fiction is an adaptation. We evolved to tell stories, they say, because they are instructive.

As currently formulated, simulation hypotheses - especially those proposed by Hobbs (1990), Pinker (1997), and Gottschall (2012) — cannot explain the sympathetic plot. First, they cannot reconcile protagonists' advantages with their distresses. If stories are designed to teach people how to problem-solve, then we should expect characters to resemble audiences- to be normal-looking and of average strength rather than attractive and strong. A story about how a good-looking dragon-killer procures a princess is of little adaptive value to an ordinary-looking vegetable-seller. ${ }^{2}$

Another weakness of simulation hypotheses is that many stories are unhelpful for dealing with real-world problems. Aside from being unrealistically capable, protagonists confront problems that no audience would encounter, including battling monsters or escaping dark netherworlds. Although these challenges may be metaphors, it is unclear how useful a protagonist's fantastical adventures would be for addressing everyday struggles or building a model of reality. ${ }^{3}$ Moreover, protagonists commonly succeed by receiving the serendipitous help

\footnotetext{
${ }^{2}$ A rejoinder might be that people enjoy imagining themselves as attractive and strong. But this rejoinder deviates from the prediction of simulation hypotheses: The story is no longer a useful simulation but simply what is pleasurable.

${ }^{3}$ A rejoinder might be that fiction serves to simulate encounters with threats that are rare but in which a person's decisions can dramatically affect their welfare, like face-offs against murderers or wild beasts. But
} 
of supernatural donors, such as talking animals or fairy godmothers (Propp, 1968; Thompson, 1946, pp. 47-67). But a serendipitous helper who solves the problem tells us little about how to solve it ourselves.

In short, simulation hypotheses argue that people tell stories to develop and test simulations of reality. But the sympathetic plot is a sub-optimal simulation. Its scenarios are unrealistic, the characters are idealized, and serendipitous helpers often resolve the problem, undermining its utility for learning how to solve problems in the future.

Building on work by media psychologists and communication scholars (Raney, 2003; Trabasso \& Chung, 2004), I here develop an account that overcomes these limitations. Like Hogan, I posit that a universal narrative structure (the sympathetic plot) recurs because it induces pleasure. But I argue that it induces pleasure not by stirring remembered emotions but by exploiting mechanisms involved in learning and cooperation. Audiences connect with sympathetic protagonists because their cognitive systems evaluate protagonists to be worthwhile social partners deserving of help. And they feel pleasure, sympathetic joy, when those characters succeed because of misfiring hedonic responses that evolved to proximately motivate cooperation.

This account is an example of a by-product hypothesis (Bloom, 2010). In contrast to simulation hypotheses and other adaptive accounts of fiction (Scalise Sugiyama, 2001; Tooby \& Cosmides, 2001), I argue that our mind is not designed to tell and receive fictional stories: Fiction might produce benefits, but it is not an adaptation. Instead, following authors such as Bloom (2010) and Nettle (2005), I argue that the psychological mechanisms supporting our interest and enjoyment in stories evolved for other purposes and have been co-opted by storytellers and cultural evolution. Some stories are shaped to socialize youth. Others are wielded to demonize rivals. The sympathetic tale, meanwhile, recurs because it entertains. In the same way that cheesecake taps Stone Age sense organs to delight consumers (Pinker, 1997), the sympathetic plot exploits systems for learning and cooperation to draw audiences in and tickle their pleasure spots.

\section{The sympathetic plot develops from intentional design and cultural selection}

I propose that sympathetic plot functions to provide pleasure (see also Tan, 1996; Vorderer, Klimmt, and Ritterfield 2004; Brewer and Lichtenstein 1982). By pleasure, I mean positive affect. Pleasurable states include the pleasures of food and sex (Georgiadis \& Kringelbach, 2012; Kringelbach, 2015), the amusement of humor (Martin, 2007), and sympathetic joy (feeling happy for another person) (Morelli et al., 2015). Although different pleasures have distinct neural signatures, they seem to share neural activity in common hedonic systems (Kringelbach \& Berridge, 2009).

Functional design can develop through at least two processes: intentional design and selection (Dennett, 1995). Intentional design refers to when individuals deliberately craft an entity to serve some end, like when someone fashions a sharp stick to stab prey. Selection refers

when Morin et al. (2019) recently tested this ordeal simulation hypothesis, they found that agentive deaths (e.g., murder) were just as frequent in a corpus of fiction as they were in a corpus of diary entries and private correspondence. They were thus unable to reject the alternative explanation that implausible threats in fiction reflect humans' general interest in social and threat-related information (Barrett et al., 2016; Blaine \& Boyer, 2018; Fessler et al., 2014; Mesoudi et al., 2006; Stubbersfield et al., 2015). 
to when (1) entities have different inheritable traits and (2) entities with certain inheritable traits spread at the expense of those with other traits, over time increasing in frequency. An example of (cultural) selection is when people experiment with and preferentially maintain weapons that more effectively kill prey, over time producing better hunting technology.

Intentional design and cultural selection likely interact to produce sympathetic tales. Intentional design is a source of variation. As people try to entertain each other, they generate stories of varying entertainment quality. But whereas the space of potential stories is profoundly vast - including descriptions of ice cubes melting or rocks doing nothing-the space of stories that people concoct is much smaller. When asked to make up stories, New York City children as young as 2 described characters performing actions or experiencing events (Sutton-Smith, 1981). Older children, meanwhile, made up stories in which characters pursued a goal, although their stories also featured content from popular tales, leaving it unclear whether kids spontaneously invent goal-directed protagonists (Botvin \& Sutton-Smith, 1977; Sutton-Smith, 1981).

Aside from inventing the basic structure of stories, storytellers also introduce variation by remodeling existing tales. Among the Ojibwe and the Winnebago, "the raconteur who has obtained complete mastery over his technique plays with his material and it is this play that becomes an important factor in the origin of different versions" (Radin, 1915, p. 43). Ntsomi story-performers in South Africa were "free to rearrange details and incidents..., indeed to make major changes and introduce modifications" (Scheub, 1975, p. 91).

Inventiveness and experimentation produce variations of stories, but the most entertaining variants proliferate through cultural selection (Singh, 2020). As audiences demand their favorites and storytellers re-use what has been effective, they retain the most pleasurable variants and fuel a selection for entertaining tales (see also Nettle, 2005). Scheub (1975, p. 90) observed the selective retention of entertaining techniques among South African $n t s o m i$ performers: "[A]n artist includes and emphasizes those elements that she delighted in during ntsomi performances that she has witnessed". He even connected this retention and the experimentation mentioned earlier to the development of the $n t s o m i$ tradition: "Considering that this process of borrowing, influencing, innovating, and combining has been going for decades, there should be no surprise that such an involved form has developed" (Scheub, 1975, p. 19).

Although intentional design and cultural selection likely interact to produce entertaining tales, their relative contributions are unclear. Intentional design explains low-level elements of stories, such as the goal-directed protagonist, while cultural selection explains why some tales diffuse across cultures or are maintained over time. But what about meso-level plot elements, such as the orphaned protagonist or punished rivals? Do people intuitively know that they should kill a protagonist's parents or does discovering the idea require years or generations of iterative experimentation? Future research will help determine precisely which elements of the sympathetic plot are intuitive and which require a search process to discover.

\section{Obstacles and sympathetic joy: The mechanics of the sympathetic plot}

The sympathetic plot provides pleasure, I argue, by evoking two sets of psychological mechanisms. First, it builds interest by confronting a goal-directed protagonist with a problem and induces satisfaction when the problem is overcome. Second, it scaffolds narrative features onto this basic plot, such as making the protagonist likable, depriving them of parents, and rewarding them at the end of the story, in turn producing a hedonic feeling of sympathetic joy. 


\section{Stories engage audiences through obstacles and resolution}

At the basis of many stories - whether or not they exhibit the sympathetic plot-is the problemsolving structure: A goal-directed protagonist confronts an obstacle and tries to overcome it (Brémond, 1970; Dundes, 1962; Lwin, 2010; Propp, 1968). This structure recurs, I argue, because it triggers mechanisms involved in learning about obstacles. It encourages people to pay attention to a story and evokes satisfaction when the obstacle is overcome (see also Black \& Bower, 1980; Brewer \& Lichtenstein, 1982; Mandler, Scribner, Cole, \& DeForest, 1980). Hearing about someone who can't achieve a goal piques our curiosity. Learning how they achieve that goal feels good.

Evolutionary logic predicts we would have mechanisms for learning from others' difficulties. In the words of cognitive scientist Jerry Hobbs (1990, p. 40), "We are planning mechanisms, continually planning our way towards goals." We identify goals, like attracting sexy mates, and encounter obstacles in their pursuit, like when sneaky rivals compete for a mate's affections. Given that other people tackle similar problems, we benefit from learning about others' hardships and the strategies that have successfully skirted them.

Three sets of psychological features suggest we are endowed with cognitive mechanisms designed to learn from others' problem-solving. First, others' obstacles intrigue us. We feel suspense when we hear about someone who has difficulty completing a goal (Fine \& White, 2002). In fact, obstacles are so potent for producing interest that they can induce suspense even when we know the outcome. Gerrig (1989) reminded Yale undergraduates of familiar outcomes, such as that George Washington was the first president of the United States. He then narrated the events leading up to these outcomes but highlighted difficulties along the way, such as that Washington was exhausted after the Revolutionary War. Even though the participants knew the outcomes and were reminded of them at the beginning of each story, they still felt suspense when they learned about obstacles (see also Delatorre, León, Salguero, Palomo-Duarte, \& Gervás, 2018).

Second, our intrigue is satisfied when we learn how a character overcomes an obstacle. Iran-Nejad (1987) documented this feeling in his experiments on reader enjoyment. He found that participants enjoyed stories with positive outcomes, such as if a camper defended himself against an intruder. But more crucially, readers liked stories more when they read how the character overcame the opponent as opposed to when it was left ambiguous. In another study, schoolchildren and college students reported enjoying stories more when the protagonist's goal seemed more important or harder to attain (Jose, 1988).

Lastly, not only are we intrigued and delighted by accounts of people confronting obstacles, but we find them memorable. American undergraduates remember incidents according to a character's goal and the strategies they used to pursue it (Black \& Bower, 1980; Bower, 1978; Brewer \& Lichtenstein, 1982; Mandler \& Johnson, 1977). They are better at remembering actions that relate to a goal, and they regard the goal as the most important element of a story (Bower, 1982; Owens et al., 1979; Thorndyke, 1977). Crucially, these mental schemas transcend cultural contexts. Mandler et al. (1980), for example, documented similar recall biases across participants in Liberia and the United States, including comparisons with unschooled Liberian children and non-literate Liberian adults. 
These three psychological responses to obstacles—our attentiveness towards them, our pleasure at learning how they are overcome, and our predisposition to remember events around them-provide evidence that humans share capacities for learning about how others confront and solve problems.

This interpretation differs from that advanced in the simulation hypotheses of Hobbs (1990) and Gottschall (2012). According to these hypotheses, fiction is adaptive: We evolved to tell and pay attention to stories, because they teach us how to solve problems. The account presented here, in contrast, proposes that we have general-purpose mechanisms for learning about others' difficulties that fiction then exploits (see also Mar, 2018). We are intrigued when we encounter someone in difficult straits, because we might end up in a similar situation and it pays to learn about the obstacle and how to overcome it. We are interested when characters confront obstacles not because it allows us to simulate problem-solving, but because it masquerades as useful information. In the same way that erotic images activate pathways of sexual arousal that evolved for copulating with real-life people, fiction taps psychological mechanisms that exist for learning about useful obstacles. It doesn't matter that a tale about a handsome orphan battling an ogre tells us little about how to solve problems in our own lives; rather, the story triggers circuits that exist for learning about obstacles, focusing our attention.

\section{The sympathetic plot induces sympathetic joy}

Once the protagonist overcomes the goal, the audience might feel some satisfaction, but most of the pleasure of sympathetic plots comes from the interaction of features including the ensuing rewards, the orphaning of the protagonist, and the protagonist's strength or attractiveness. These features, I argue, interact to induce sympathetic joy. First, the story creates a sympathetic protagonist who audiences are motivated to help, appealing to cognitive mechanisms for finding social partners and allocating cooperation. The protagonist then succeeds, and audiences feel a surge of sympathetic joy. This emotion evolved to motivate cooperation, but it misfires when we represent an imaginary character as a potential social partner.

\section{People feel happy for people they want to help}

People feel pleasure in response to other people's good fortune. Researchers variously refer to this feeling as symbedonia (Royzman \& Rozin, 2006), positive empathy (Morelli et al., 2015), vicarious reward (Mobbs et al., 2009), empathic joy (Batson et al., 1991), and empathic happiness (Light et al., 2015). Following Royzman and Rozin (2006), I call it sympathetic joy.

Some researchers argue that sympathetic joy serves to motivate cooperation (Smith et al., 1989; Telzer et al., 2010). They point out that if you expect that someone's success will feel good, then you will be motivated to help them and feel the promised tickle (see also Telle and Pfister, 2016). In the same way that the pleasures of sex, sugar, and safety entice us (Rozin, 1999), a beneficiary's success feels good so as to encourage us to reproduce it.

Converging lines of research suggest that we feel happy for people we want to help. US participants reported greater sympathetic joy towards individuals to whom they felt more attached, such as best friends, compared to casual acquaintances (Royzman \& Rozin, 2006). Similar effects have been documented when studying brain activity. Subjects showed greater activity in hedonic systems when in-group members succeeded compared to out-group members 
(Hackel et al., 2017) and when friends benefited compared to antagonists (Braams et al., 2014). Subjects who felt more attached to a target-NYU students who identified more with their university, Los Angeles young adults who identified more with their family, and Dutch young adults who reported being closer to their mothers and friends - showed greater hedonic activity when the target benefited compared to subjects who felt less attached to a target (Braams \& Crone, 2017; Hackel et al., 2017; Telzer et al., 2010).

A second set of studies has found that people who experience or anticipate joy in others' successes are more likely to help them. Pittinsky and Montoya (2016) used survey results, expert evaluations of teaching, and student outcomes of 1,200 American teachers to investigate the correlates and consequences of teachers' sympathetic joy. They found that teachers who reported greater joy in their students' successes created higher-quality learning environments and had higher achieving students. Batson et al. (1991) and Smith et al. (1989) tested whether the anticipation of seeing a happy beneficiary motivated helping. It did: American undergraduates who expected to see a positive reaction were more likely to help, although in one study, this effect disappeared when the participants were asked to empathize with the recipient.

These findings indicate that people feel happy for a beneficiary when the target is someone they want to help. If stories develop to induce sympathetic joy, then they should feature characters who audiences most want to assist. What should those ideal beneficiaries look like?

\section{People want to help individuals who are competent, willing, and in need}

The most important ultimate factors motivating someone to help are kinship and reciprocity (Baumard et al., 2013; West et al., 2007). In short, our psychology seems designed to allocate help to relatives and people who will help us in return. Convincing an audience that a protagonist is a family member seems difficult, especially when the same story is told to many individuals. But convincing the audience that the protagonist is an appealing cooperative investment is much easier.

There are at least two sets of traits that make someone a valuable cooperative partner and which people esteem in others (Barclay, 2013; Cuddy et al., 2008; Fiske et al., 2007; Kummer, 1978; Tooby \& Cosmides, 1996):

1. Competence. A valuable partner is strong, fast, talented, good-looking, courageous, clever, and high status. That is, they have attributes that reliably produce shareable benefits, both through intentional action (e.g., coalitional support) and positive externalities (e.g., popularity by association).

2. Willingness to help (or warmth). A valuable partner is generous, sincere, trustworthy, moral, and genuinely invested in us. That is, they are willing to help us and remain with us when things get difficult. A partnership becomes much easier when the people involved want the same things; it becomes harder when their wants diverge, such as if one partner regards the other's goal as wrong (and likely to draw disapproval).

People are predisposed to help strangers with appealing traits, presumably to initiate relationships with them (Pisor \& Gurven, 2016, 2018). Maestripieri et al. (2017) reviewed the vast literature demonstrating people's biases towards attractive individuals, including that attractive marathon runners receive larger online donations (Raihani \& Smith, 2015) and 
attractive waitresses get larger tips from men, regardless of the quality of the service (Lynn, 2009; Lynn \& Simons, 2000). These cooperative biases extend to strangers with appealing traits other than physical attractiveness. Students at UCSB played the ultimatum game (an economic game) with partners who were represented with face photographs (Eisenbruch et al., 2016). A separate group of students rated the same photographs for attributes such as health, dominance, and social status. Despite having no previous relationship with the targets, participants gave more money to partners represented by appealing faces, such as those that appeared healthy, attractive, prosocial, and high status.

The ideal beneficiary should not only be a valuable social partner; they should suffer too. People have compassion. We are motivated to help people in need (see Batson, Ahmad, Lishner, \& Tsang, 2002; Goetz, Keltner, \& Simon-Thomas, 2010 for reviews). This motivation is influenced both by how close we feel towards a target (Greitemeyer, 2010). We help needy family members more than needy good friends and needy acquaintances more than needy nearstrangers (Cialdini et al., 1997). Meanwhile, an enormous experimental literature, including studies in the United States, Germany, Japan, and Nigeria, shows that people prefer to help individuals whose suffering is out of their control (Rudolph et al., 2004). As with our generosity towards appealing would-be partners, compassion likely exists to secure cooperative relationships (Goetz et al., 2010). We help the needy, especially when help is cheap for us and beneficial to them, to secure their gratitude and reap the benefits of their friendship in the future (Trivers, 1971).

In summary, a technology designed to produce sympathetic joy should create a character who is capable, warm, and who has goals that are relatable and uncontroversial. They should be in need, arousing our compassion, although their suffering should be out of their control.

\section{Explaining stories}

\section{Protagonists of sympathetic tales are ideal beneficiaries and audiences regard them as friends}

Stories should most effectively evoke sympathetic joy when audiences want to help protagonists and especially when they regard protagonists as attractive social partners. Narrative patterns and studies of how people represent and respond to characters show that this is the case: Protagonists everywhere are appealing and in distress; audiences, in turn, develop warm feelings towards them.

\section{Protagonists are appealing.}

The protagonists of the world's folktales are appealing. Gottschall (2005) coded the features of 568 female protagonists and 392 male protagonists from 658 tales from around the world. The tales, selected as a globally representative sample of folktales, frequently starred studs. Physical attractiveness was mentioned for $22 \%$ of male protagonists and $51 \%$ of female protagonists-and nearly all were attractive. In fact, of the 568 female protagonists coded, only 8 were described as unattractive. Characters were also prosocial: $42 \%$ of female protagonists were "primarily motivated to help others"; in contrast, very few antagonists (14\% female, $5 \%$ male) had prosocial inclinations (data for male protagonists were not reported). Lastly, characters were competent; they had skills or abilities that produced benefits. A third of male protagonists exhibited heroism, 
while a fifth of all males were said to be best described as courageous.

In her cross-cultural study of orphan stories, Kimball (1999) also noted the appealing traits of protagonists. Orphans were sometimes witty (7/50) and often virtuous (29/50). Some were hardworking, industrious, and brave; others' merits were never explicitly stated, although they were "observable as the orphan endures abuse without complaint" (p. 565). In fact, Kimball only mentioned the negative traits of two orphan-protagonists: The Poor Turkey Girl (Zuni), who refrained from visiting a flock of turkeys who helped her, and Coolnajoo (Wabanaki), who acted as a fool to spite his uncle. Notably, these two were the only orphan-protagonists to suffer at the end of their stories.

The heroes of hero-ogre stories around the world were also appealing, exhibiting unique courage and strength (Jobling, 2001). They could kill villages of cannibals (Mbundu of Angola), shoot arrows through armor (Apache of American Southwest), and decapitate ogres with a slash of a thumbnail (Micronesia). And they were good: "In all the stories, the hero's actions benefit the in-group as a whole" (Jobling, 2001, p. 260).

Finally, these trends seem to apply to Western stories. When Johnson, Carroll, Gottschall, \& Kruger (2008) studied the characters of 201 canonical nineteenth century British novels, they found that protagonists typically valued their friends, pursued education, and helped non-kin. Antagonists, meanwhile, rarely exhibited those traits.

\section{Protagonists are the victims of uncontrollable misfortune.}

Stories everywhere subject protagonists to tragic distress. A common trope is to make the protagonist an orphan (Henneberg, 2010). In a sample of 124 award-winning American children's novels, $18 \%$ featured orphan protagonists; $37 \%$ featured protagonists who were removed from their parents in any way (Mattix, 2012). A similar analysis of top-grossing animated children's movies found that $18 \%$ included the death of a parent, much more frequent than deaths of romantic interests (6.7\%), children (4.4\%), or close friends (4.4\%) (Colman et al., 2014). Orphans are so common that the motif wiki TV Tropes includes more than 25 pages describing orphan-related motifs, including "Disappeared Dad" (Forest Gump), "Doorstop Baby" (Harry Potter), "Heartwarming Orphan" (James of James and the Giant Peach), and "Street Urchin" (Oliver Twist) (TV Tropes, 2019b). A page on "Death by Childbirth" underscores the trope's potency by pointing to its statistical improbability": "So sad, so tragic, so heartwrenching... such a goldmine of a plot device. Nothing impossible about it, but the statistics are ridiculously high, especially for any industrialized nation" (TV Tropes, 2019a).

Orphan protagonists dominate non-Western stories, too. In Igbo (Nigeria) stories, "heroes and heroines were motherless children, orphans or paupers, who always vanquished the more privileged by miraculous or magical means" (Amadiume, 1987, p. 85). In Toraja (Sulawesi) stories, "there is repeated mention of orphans who are neglected and mistreated, only to achieve glory later on" (Adriani and Kruijt, 1970, p. 140). In Karen (Myanmar) folklore, "many tales recount episodes in which an orphan exercises his uncanny powers, usually in defense of some

\footnotetext{
${ }^{4}$ Using data from both the CIA World Fact Book and the U.S. Department of Health and Human Services, Administration for Children and Families, Administration on Children, Youth, and Families, Mattix (2012) estimated that the less than one percent of school-age children in the United States ( 408,000 of 63 million) are orphans.
} 
weaker person who he saves or helps to get the better of his foes" (Marshall, 1922, p. 269). Another common sympathy-inducing trope is the youngest sibling protagonist (e.g., Muria Gond of central India: Elwin, 1947, p. 237; Nenet of Siberia: Golovnev, 1997, p. 149; Ainu of Japan: Batchelor, 1927, pp. 337-342, 364-365). As with being an orphan, being a youngest sibling is out of a character's control but subjects them to immediate disadvantage, especially when they are bullied.

\section{Audience members represent characters as people and are attached to appealing characters.}

People regard characters as other people, at least partly. They speak to characters, feel sorry for them when they make mistakes, and feel comfortable around characters as they would around friends (Giles, 2010; Klimmt et al., 2006). Men who watch more news shows and women who watch more sitcoms report being more satisfied with their friendships, presumably because they represent characters as friends (Kanazawa, 2002). Readers of Harry Potter and Twilight admit to missing characters after finishing the book series (Fan Forum, 2008; Harry Potter Forums, 2011), while American viewers of soap operas have physically assaulted actors who play villains (Winsey, 1979; cited in Hoffner and Cantor, 1991). In 1969, 5,000 viewers gathered at a church in Lima, Peru to watch the filming of a main character's wedding. According to one newspaper, "People were dressed in their best outfits; several people fainted, gripped by their emotions" (Singhal et al., 1994, p. 8). Bezdek et al. (2013) coded viewers' participatory responses to films, including replotting ("He should've tried to hide behind a seat or something.") and stated preferences for outcomes ("I hope there's no one in the house."). They found that, aside from emotional outbursts ("Oh no!", "Oh my god!"), viewers' most common participatory responses were instructions to the characters on how to solve problems, like "Get out of there!" or "Just do it!"

The claim that we represent fictional characters as other people may at first seem strange. Children as young as 5 recognize the distinction between reality and fantasy (Samuels \& Taylor, 1994; Skolnick \& Bloom, 2006; Woolley \& Phelps, 1994). If people understand that characters are fictional, why should they represent them as other people? Why should they miss them, hate them, pity them, and yell helpful instructions? Scholars refer to this puzzle as the paradox of fiction: Although we understand fictional entities to be made-up, we emotionally respond to them as if they were real (Friend, 2016; Radford \& Weston, 1975).

The resolution to the paradox of fiction is simple: Many of our responses to stimuli occur regardless of whether they are encoded as real. Participants are less willing to consume sugar labeled "not sodium cyanide, not poison" compared to sugar labeled "sucrose, table sugar", even when they observe the same sugar poured into both bottles (Rozin et al., 1990). They regard feces-shaped fudge to be less appealing than disc-shaped fudge and vomit-shaped rubber to be more repulsive than a sink stopper, even when they are assured that the fudges and the rubbers have the same compositions (Rozin et al., 1986). They are sexually aroused by erotic imagery, even when they understand that the targets are inaccessible or imaginary. Of course, our responses to mislabeled sugar, stool-shaped fudge, and erotic imagery are tempered compared to our responses to real versions of those stimuli. Nevertheless, as Bloom (2010, p. 169) summarized, "our minds are partially indifferent to the contrast between events that we believe to be real or that are imagined to be real." Fictional characters evoke many of the psychological responses that real humans do, even when audiences understand that they are imaginary. 
Given that we treat characters (at least partly) as individuals, it should be of little surprise that we find the same traits appealing in story-characters as we do in real-life social partners. Not only do audience members like characters with attractive traits (Hoffner \& Cantor, 1991; Krakowiak \& Oliver, 2012; Weber et al., 2008; Zillmann \& Cantor, 1977), but they develop friendly feelings towards them, too. Elementary schoolchildren in Illinois had stronger one-sided relationships - including missing a character when they're not around and wanting to meet them—with characters who appeared attractive, intelligent, and strong (Hoffner, 1996). Midwestern American undergraduates, meanwhile, had stronger relationships with characters they considered socially attractive (e.g., friendly) and competent (e.g., capable of getting things done) (Rubin \& McHugh, 1987).

Whereas characters' likable traits encourage friendly feelings, their difficult circumstances seem to invite compassion. Although there is little to no experimental research on how readers respond to mistreated children protagonists, Keen's (2007) survey of an online discussion group provides preliminary evidence. She found that "many readers report that novels in which child characters are subjected to cruel or unfair treatment evoke empathy" (p. 69). ${ }^{5}$ And notably, readers reported these responses while acknowledging that they came from different backgrounds. As one reader wrote, "In both [Jane Eyre and David Copperfield] my strongest empathetic responses were aroused by scenes of abuse by cruel relatives and abusive school teachers, even though I was a happy lovingly-nurtured child who adored my teachers and school" (Keen, 2007, pp. 69-70).

\section{The protagonist's journey provides a series of nested obstacles}

Sympathetic protagonists frequently go on journeys, encountering monsters, gate-keepers, and redirection along the way. The account developed here offers at least two reasons for this trope. First, a journey enhances the perceived difficulty of a goal and, as a consequence, good feelings. If, as Jose's (1988) findings suggest, we experience greater joy when a character completes a more difficult goal, then forcing the character to embark on a complicated and dangerous series of tasks (e.g., escaping a cyclops, skirting sirens) is a simple way of boosting pleasure when the protagonist finally succeeds.

A second explanation for the frequency of journeys is that they allow stories to include a series of related obstacles. A story might include several obstacles for many reasons, including that (1) the story is longer and requires successive problems to maintain interest, (2) the story

\footnotetext{
${ }^{5}$ In her prompt, Keen defined an "empathetic response" as "one in which you felt with a fictional character or another aspect of the fiction" (emphasis in original), contrasting it with a "sympathetic reading experience, which does not necessarily entail shared feelings"

(https://list.indiana.edu/sympa/arc/victoria/2004-11/msg00156.html). But distinguishing between an empathetic response (roughly, feeling as someone else) and a sympathetic response (feeling for them) can be difficult. Consider a father who sees his daughter win a spelling bee. They have a shared feeling (happiness), but there many reasons why they might share this feeling. The father might mirror or simulate his daughter's emotion, or her triumph may remind him of his own victories, or he may feel happy for her. He would report an empathetic response yet remain ignorant of the mechanism producing the shared feeling. This ignorance also applies to the readers who responded to Keen's question. They understand their emotional response to the orphan's plight as "empathetic", but their shared feeling may occur for many reasons, including being sad for the orphan.
} 
describes feats or trials to show off the protagonist's special abilities, and (3) as just discussed, the story enhances the perceived difficulty of attaining the goal. But unrelated obstacles cannot be piled onto each other. Instead, storytellers must causally connect the conflicts a protagonist encounters, ideally unifying them under a single goal (Bower, 1982; Trabasso \& Sperry, 1985; Trabasso \& van den Broek, 1985; Zacks et al., 2007). Journeys provide this structure. They establish an overarching goal (like destroying a ring) and string a series of obstacles leading up to it (like avoiding Orcs and escaping a spider), enabling longer, coherent sympathetic tales.

\section{Explaining success}

Throughout this paper, I have reviewed many stories that conclude with the protagonist's success. Here I review psychological evidence showing that this success evokes sympathetic joy. I then consider tales that seem to violate the sympathetic template: tragedies.

\section{People feel sympathetic joy when characters they like succeed.}

A viewer of the Indian soap opera "Hum Log" showed how intense this vicarious pleasure can be in a letter she wrote to the television network:

Congratulations on the wedding of Dr. Ashwini and Badki. When the wedding was being telecast, my family and I could not control the tears of joy, and when the newlywed couple was blessed for the first time, our excitement knew no bounds. (Sood and Rogers, 2000, p. 400)

Researchers have demonstrated this joy in experiments (Zillmann, 1995). In one study, American schoolchildren watched a short film in which a boy was either nice, neutral, or mean (Zillmann \& Cantor, 1977). Afterwards, the boy either received a new bike and delightfully rode off or fell off his bike and cried. Children felt happy when the nice protagonist got a bike or the mean one fell. They felt sad, in contrast, when the nice protagonist fell or his mean counterpart got lucky. In another study, participants watched Alfred Hitchcock's Vertigo and Ridley Scott's Blade Runner (Trabasso and Chung, 2004; described in Oatley, 2011). The experimenters stopped the films twelve times, and at each point, participants either evaluated the success of different characters or reported their emotions. When the protagonist succeeded or the antagonist failed (as rated by half of the participants), viewers felt positive emotions like happiness and relief. When things went badly for the protagonist or swimmingly for the antagonist, in contrast, viewers felt negative emotions (see also Zillmann, Taylor, \& Lewis, 1998).

\section{Unsympathetic characters suffer misfortune more often.}

If the audience's feelings track how appealing they find the protagonist, then protagonists who fail should often have unappealing traits. This seems to be the case. Literary scholars appreciate that protagonists of European tragedies tend to exhibit a tragic flaw, a misjudgment or moral failing that propels their eventual demise (Bushnell, 2008). The failing can manifest as an unacceptable goal, like a taste for pedophilia, or ugly methods for attaining it, like killing a family 
member. Stories as diverse as Richard III, Macbeth, The Picture of Dorian Gray, Lolita, and Scarface pair a character's moral faults with their eventual demise (Booker, 2004; Bushnell, 2008).

Plots that involve the sympathetic protagonists' ultimate misfortune often compensate with redemption.

Stephen King (2002, p. 169) wrote, "No one likes to root for a guy over the course of three hundred pages only to discover that between chapters sixteen and seventeen the pig ate him." Yet sympathetic plots sometimes end with a likable protagonist's downfall. An example is the Ainu story of Kutri and Yai-mah (Batchelor, 1927, pp. 437-448). Declared the most handsome man, Kutri was also strong, swift, clever, keen-sighted, charismatic, an astute tracker, and a talented fisherman. Yai-mah had a lustrous, moon-round face and a cerulean, well-defined tattoo; she danced, played the harp, brought water without spilling, and maintained a respectable garden plot. The two were instantly enamored, but both were betrothed as children to mean, useless, ugly partners. When Kutri and Yai-mah ran away, their ugly exes pursued them. The exes shot Kutri with a poison arrow. After he died, Yai-mah killed herself.

The story of Kutri and Yai-mah violates our expectations. It follows the structure of the sympathetic plot (with almost cartoonishly appealing social partners) but distorts it by leaving the protagonists' goals unfulfilled, even killing them. Nevertheless, it ends with feel-good justice. After the lovers' deaths, the ugly exes approached the couple's house. One of the exes kicked Yaimah's dead body, piercing himself with the poisoned arrow. He died immediately. The other ex burned down the house, attracting the attention of the couple's faithful dogs. They bit the vengeful arsonist. Within days, she began scratching, barking, and foaming at the mouth. Both ugly exes lived cursed afterlives among demons, while Kutri and Yai-mah enjoyed their afterlives in bliss.

The point is that even violations of the sympathetic plot induce good feelings by offsetting (to some extent) the protagonist's misfortune with redemption. Romeo and Juliet ended not with the star-crossed lovers' deaths but with their families concluding their feud and promising to immortalize the children in golden statues. After the blameless, titular character of Antigone hanged herself, the son and then the wife of the king who ordered her death killed themselves too, leaving the king alone and despairing. The film Titanic showed the death of the protagonist's lover (Jack), but then revealed that her cruel fiancé committed suicide, that she lived a full life, and that she was reunited with Jack in a mesmerizing afterlife. Chinese tragedies paired the death of a sympathetic protagonist with cosmic justice, too (Wallace, 2013). In the $13^{\text {th }}$ century play The Injustice to Dou E, a young widow was framed for murder and forced to confess. She was beheaded, but before her execution, she prophesied unnatural events in the case of her innocence. Her blood did not drip on the ground, snow fell in midsummer, and the region suffered a drought. Three years later, her father ordered a reinvestigation and the perpetrators were properly punished.

Redemption softens the blow of tragic endings, but it fails to explain why sympathetic plots take terrible turns. Instead, psychological responses distinct from sympathetic joy likely contribute to people's positive appraisals of tragedies (Menninghaus et al., 2017; Oliver \& Raney, 2011; Tan, 1996). Oliver and Bartsch (2010) found evidence that stories regarded as meaningful or emotionally impactful produce positive experiences beyond a basic hedonic punch. When the authors surveyed participants about the most recent film they watched, they found that respondents rated movies along a dimension the authors called "moving/thought 
provoking", including items such as "The movie was thought provoking" and "I was moved by this movie". Responses to these items clustered distinctly from responses to items such as "The movie was entertaining" and "I had a good time watching this movie", indicating that people represented them as separate from pure enjoyment. Deviations from the sympathetic plot can persist when they evoke positive psychological responses aside from sympathetic joy.

\section{Concluding remarks}

\section{Why this pleasure but not that pleasure?}

Why is sympathetic joy so important for producing narrative structure when there exist other ways of inducing pleasure? We enjoy hearing about powerful weapons, magical items, monsters, beautiful landscapes, and sexual gossip, yet these have featured little in the proposed account. Why?

Many stimuli focus our attention or produce hedonic feelings (Kringelbach \& Berridge, 2009). But sympathetic joy is special, because inducing it requires manipulating cognitive representations of a character and what happens to them. Insofar as we enjoy hearing about monsters or sexual escapades, a storyteller can include them in a tale and produce the accompanying feelings. Evoking sympathetic joy, in contrast, demands defining character and plot. It demands presenting an appealing character, subjecting them to early distress, confronting them with an obstacle, and having them succeed. If we start with the basic, attention-grabbing substrate - a goal-directed protagonist confronts an obstacle-we can modify it in many ways to make it entertaining, such as by introducing fantastical artifacts or indications of betrayal. But among the most impactful changes will be those serving to induce sympathetic joy.

Importantly, sources of pleasure aside from sympathetic joy also require modifications to plot or character, resulting in distinct narrative archetypes. Trickster tales feature characters who are often unappealing, mentally abnormal, and horny or gluttonous (Abrams \& Sutton-Smith, 1977; Babcock-Abrahams, 1975; Radin, 1956). These tricksters violate social norms, engage in activities involving excrement and sexuality, and trick others or are tricked themselves. Such elements of character and plot embody the combination of alarm and distance considered central for experiencing humor (Gervais \& Wilson, 2005; McGraw \& Warren, 2010), suggesting that trickster tales are, in a sense, laughter machines. Origin stories, meanwhile, seem to arrange events to evoke the satisfying hit of learning a causal relationship - a version of the Aha! experience (Shen et al., 2016; Topolinski \& Reber, 2010) or what Gopnik (1998) referred to as the "orgasm" of explanation. As long as triggering certain pleasures requires manipulating representations of characters and events, those pleasures are expected to be important in shaping narratives.

Of course, stories are far from the only technologies that induce pleasure. Sweets, drugs, pornography, music festivals, and the like button are just some of the many cultural products apparently engineered to hijack reward pathways and spark good feelings. Moreover, as these examples demonstrate, different pleasures are induced by different technologies. The delight triggered when eating a chocolate chip cookie cannot be activated by watching Harry Potter or vice versa. Different pleasures are evoked by very different stimuli, resulting in a diversity of pleasure-technologies. 


\section{Five predictions}

I had two aims in this paper. First, I proposed that a particular narrative structure, the sympathetic plot, is ubiquitous, appearing in books, films, myths, and folk tales everywhere. This proposal yields testable predictions, including the following two:

1. The sympathetic plot should appear in the vast majority of the world's folkloric traditions, regardless of societies' subsistence strategies or levels of social complexity and controlling for similarities that might result from diffusion or shared cultural history.

2. For any story with a sympathetic plot that has variants over a geographic range (e.g., many versions of Cinderella across Europe), the primary and secondary features (see Table 1) should vary less across variants than do other features of the stories.

Table 1

Features of the sympathetic plot and their hypothesized psychological responses

Feature of the sympathetic plot Psychological response

1. A protagonist $(\mathrm{P})$ has a goal. Builds interest by triggering mechanisms

for learning about problem-solving (Builds interest); Motivates audience to help P (Motivates helping)

苞

2. The goal is relatable or justifiable. Motivates helping

3. $\mathrm{P}$ confronts an obstacle.

Builds interest; Motivates helping

4. P overcomes the obstacle.

Resolves interest about how to overcome obstacle, delivering satisfaction; Produces sympathetic joy

5. P reaps rewards. Produces sympathetic joy

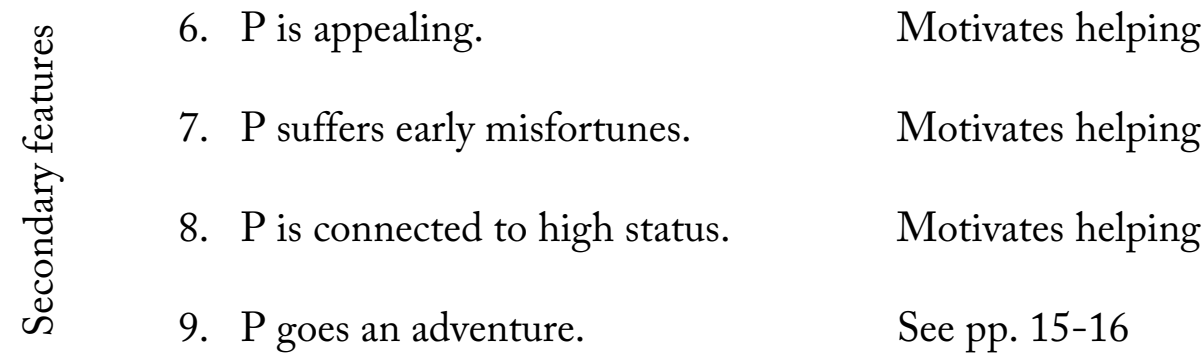


10. P's opponents are repulsive and Motivates helping formidable.

11. Anyone who opposes $\mathrm{P}$ reforms or is Produces sympathetic joy punished.

I then argued that the sympathetic plot recurs because it is a technology for producing pleasure. It works by first presenting a goal-directed protagonist with an obstacle, building interest. It then establishes the protagonist as an appealing cooperative partner, so that when they succeed, audiences experience sympathetic joy, a hedonic state that normally occurs to motivate helping. I used this account to explain the features of the sympathetic plot, summarized in Table 1. This hypothesis also generates a set of predictions, including the following:

3. The hedonic neural activity that occurs at the triumphant end of a sympathetic tale should match the neural activity involved in sympathetic joy more than the neural activity during other hedonic states, such as the pleasure of remembering past instances of one's own success.

4. People's desire to help a character should predict their hedonic state when that character succeeds.

5. Protagonists' traits and goals and the features of opponents should vary according to local cultural contexts. In particular, protagonists should exhibit those traits that people in that context prefer in their social partner; protagonists' goals should be those that people pursue and consider justifiable; and opponents should exhibit traits that make them formidable and unappealing. As people's social partner preferences, goals, and conceptions of formidability and repulsion change, the stories they tell should transform, too.

\section{Summary}

Why do people everywhere tell stories about abused stepdaughters who marry royalty and revel in awarded riches? Whence all the virtuous orphans? The answer, I have argued, is entertainment. Tales in which a likable main character overcomes difficulty and reaps rewards create a compelling cognitive dreamscape. They twiddle psychological mechanisms involved in learning and cooperation, narrowing attention and inducing sympathetic joy. Story imitates life, or at least the elements of life to which we've evolved pleasurable responses.

\section{Acknowledgments}

Maarten Boudry, Luke Glowacki, Jonathan Gottschall, Patrick Hogan, Raymond Mar, Keith Oatley, and an anonymous reviewer provided helpful comments on earlier versions of this manuscript. This research was funded by a graduate research fellowship from the National Science Foundation and, through IAST, by the French National Research Agency (ANR) under the Investments for the Future (Investissements d'Avenir) program, grant ANR-17-EURE0010 . 


\section{Literature cited}

Abrams, D. M., \& Sutton-Smith, B. (1977). The development of the trickster in children's narrative. The Journal of American Folklore, 90(355), 29-47.

Adriani, N., \& Kruijt, A. C. (1970). The Bare'e-speaking Toradja of central Celebes (the East Toradja), vol. 3. Human Relations Area Files.

Alidou, O. (2002). A "Cinderella" tale in the Hausa Muslim women's imagination. Comparative Literature, 54(3), 242-255.

Amadiume, I. (1987). Male daughters, female husbands: Gender and sex in an African society. Zed Books.

Babcock-Abrahams, B. (1975). "A tolerated margin of mess": The trickster and his tales reconsidered. Journal of the Folklore Institute, 11(3), 147-186.

Barclay, P. (2013). Strategies for cooperation in biological markets, especially for humans. Evolution and Human Behavior, 34(3), 164-175. https://doi.org/10.1016/j.evolhumbehav.2013.02.002

Barrett, H. C., Peterson, C. D., \& Frankenhuis, W. E. (2016). Mapping the cultural learnability landscape of danger. Child Development, 87(3), 770-781.

https://doi.org/10.1111/cdev.12495

Bastian, A. (2005). The psychic unity of mankind and some elementary symbols. In Klaus Peter Köpping (Ed.), Adolf Bastian and the psycbic unity of mankind: The foundations of anthropology in nineteenth century Germany (pp. 179-185). Lit Verlag.

Batchelor, J. (1927). Ainu life and lore: Echoes of a departing race. Kyobunkwan.

Batson, C. D., Ahmad, N., Lishner, D. A., \& Tsang, J.-A. (2002). Empathy and altruism. In C. R. Snyder \& S. J. Lopez (Eds.), Handbook of positive pasychology. Oxford University Press. https://doi.org/10.1093/oxfordhb/9780199328079.013.11 Abstract

Batson, C. D., Batson, J. G., Slingsby, J. K., Harrell, K. L., Peekna, H. M., \& Todd, R. M. (1991). Empathic joy and the empathy-altruism hypothesis. Journal of Personality and Social Psychology, 61(3), 413-426.

Baumard, N., André, J.-B., \& Sperber, D. (2013). A mutualistic approach to morality: the evolution of fairness by partner choice. Behavioral and Brain Sciences, 36(1), 59-78. https://doi.org/10.1017/S0140525X11002202

Bezdek, M. A., Foy, J. E., \& Gerrig, R. J. (2013). "Run for it!": Viewers' participatory responses to film narratives. Psychology of Aesthetics, Creativity, and the Arts, 7(4), 409-416. https://doi.org/10.1037/a0034083

Black, J. B., \& Bower, G. H. (1980). Story understanding as problem-solving. Poetics, 9, 223250.

Blaine, T., \& Boyer, P. (2018). Origins of sinister rumors: A preference for threat-related material in the supply and demand of information. Evolution and Human Behavior, 39(1), 67-75. https://doi.org/10.1016/j.evolhumbehav.2017.10.001

Bloom, P. (2010). How pleasure works: The new science of why we like what we like. W. W. Norton \& Company.

Booker, C. (2004). The seven basic plots: Why we tell stories. Continuum.

Botvin, G. J., \& Sutton-Smith, B. (1977). The development of structural complexity in children's fantasy narratives. Developmental Psychology, 13(4), 377-388.

https://doi.org/10.1037/0012-1649.13.4.377 
Bower, G. H. (1978). Experiments on story comprehension and recall. Discourse Processes, 1(3), 211-231. https://doi.org/10.1080/01638537809544437

Bower, G. H. (1982). Plans and goals in understanding episodes. Advances in Psychology, 8, 2-15. https://doi.org/10.1016/S0166-4115(08)62676-X

Bower, G. H., \& Morrow, D. G. (1990). Mental models in narrative comprehension. Science, 247(4938), 44-48. https://doi.org/10.1126/science.2403694

Boyd, B. (2009). On the origin of stories: Evolution, cognition, and fiction. Harvard University Press.

Braams, B. R., \& Crone, E. A. (2017). Peers and parents: A comparison between neural activation when winning for friends and mothers in adolescence. Social Cognitive and Affective Neuroscience, 12(3), 417-426. https://doi.org/10.1093/scan/nsw136

Braams, B. R., Güroğlu, B., de Water, E., Meuwese, R., Koolschijn, P. C., Peper, J. S., \& Crone, E. A. (2014). Reward-related neural responses are dependent on the beneficiary. Social Cognitive and Affective Neuroscience, 9, 1030-1037. https://doi.org/10.1093/scan/nst077

Brémond, C. (1970). Morphology of the French folktale. Semiotica, 2(3), 247-276. https://doi.org/10.1515/semi.1970.2.3.247

Brewer, W. F., \& Lichtenstein, E. H. (1982). Stories are to entertain: A structural-affect theory of stories. Journal of Pragmatics, 6, 473-486.

Bushnell, R. (2008). Tragedy: A short introduction. Blackwell Publishing.

Campbell, J. (1949). The hero with a thousand faces. Pantheon Books.

Carroll, J. (2011). Reading human nature: Literary Darwinism in theory and practice. State University of New York Press.

Carroll, J., Gottschall, J., Johnson, J. A., \& Kruger, D. J. (2012). Graphing Jane Austen: The evolutionary basis of literary meaning. Palgrave Macmillan.

Casalis, E. (1861). The Basutos; or twenty-three years in South Africa. James Nisbet \& Co. https://archive.org/details/basutosortwentyt00casa

Cialdini, R. B., Brown, S. L., Lewis, B. P., Luce, C., \& Neuberg, S. L. (1997). Reinterpreting the empathy-altruism relationship: When one into one equals oneness. Journal of Personality and Social Psychology, 73(3), 481-494. https://doi.org/10.1037/0022-3514.73.3.481

Clasen, M., Kjeldgaard-Christiansen, J., \& Johnson, J. A. (2020). Horror, personality, and threat simulation: A survey on the psychology of scary media. Evolutionary Behavioral Sciences, 14(3), 213-230. https://doi.org/10.1037/ebs0000152

Colman, I., Kingsbury, M., Weeks, M., Ataullahjan, A., Bélair, M. A., Dykxhoorn, J., Hynes, K., Loro, A., Martin, M. S., Naicker, K., Pollock, N., Rusu, C., \& Kirkbride, J. B. (2014). CARTOONS KILL: Casualties in animated recreational theater in an objective observational new study of kids' introduction to loss of life. British Medical Journal, 349, g7184. https://doi.org/10.1136/bmj.g7184

Cook, V. (1965). Lord Raglan's hero -- A cross cultural critique. The Florida Anthropologist, 18, 147-154.

Cox, M. R. (1893). Cinderella: Three hundred and forty-five variants of Cinderella, Catskin, and Capo'Rushes. David Nutt.

Cuddy, A. J. C., Fiske, S. T., \& Glick, P. (2008). Warmth and competence as universal dimensions of social perception: The stereotype content model and the BIAS map. In Advances in Experimental Social Psychology (Vol. 40). https://doi.org/10.1016/S0065- 
2601(07)00002-0

Delatorre, P., León, C., Salguero, A., Palomo-Duarte, M., \& Gervás, P. (2018). Confronting a paradox: A new perspective of the impact of uncertainty in suspense. Frontiers in Psychology, 9, 1-13. https://doi.org/10.3389/fpsyg.2018.01392

Dennett, D. C. (1995). Darwin's dangerous idea: Evolution and the meanings of life. Simon \& Schuster.

Donaldson, S. N. (2014). The secret life of the cross-cultural fairy tale: A comparative study of the Indonesian folktale "Bawang Merah, Bawang Putib" and three European fairy tales. Portland State University.

Dracott, A. E. (1906). Simla village tales: Or, folk tales from the Himalayas. John Murray. https://archive.org/details/cu31924023641156

Dundes, A. (1962). The morphology of North American Indian folktales. Indiana University.

Dundes, A. (1982). Cinderella, a casebook. University of Wisconsin Press.

Dundes, A. (1987). Parsing through customs: Essays by a Freudian folklorist. University of Wisconsin Press.

Dunlop, J. C. (1888). History of prose fiction. George Bell \& Sons. https://archive.org/stream/historyofprosefi01dunl\#page/n529/mode/2up

Dutton, D. (2005, May 8). Once upon a time. Washington Post. http://www.washingtonpost.com/wpdyn/content/article/2005/05/05/AR2005050501385.html

Eisenbruch, A. B., Grillot, R. L., Maestripieri, D., \& Roney, J. R. (2016). Evidence of partner choice heuristics in a one-shot bargaining game. Evolution and Human Behavior, 37(6), 429-439. https://doi.org/10.1016/j.evolhumbehav.2016.04.002

Elwin, V. (1947). The Muria and their ghotul. Oxford University Press.

Fan Forum. (2008). RBD/Rebelde \#25: 25 threads of pure RBD awesomeness, and we still can't get enough. Fan Forum. http://www.fanforum.com/f29/rbd-rebelde-25-25-threads-pure-rbdawesomeness-we-still-cant-get-enough-62840322/index15.html

Fessler, D. M. T., Pisor, A. C., \& Navarrete, C. D. (2014). Negatively-biased credulity and the cultural evolution of beliefs. PLOS ONE, 9(4), 1-8. https://doi.org/10.1371/journal.pone.0095167

Fine, G. A., \& White, R. D. (2002). Creating collective attention in the public domain: Human interest narratives and the rescue of Floyd Collins. Social Forces, 81(1), 57-85. https://doi.org/DOI 10.1353/sof.2002.0046

Fiske, S. T., Cuddy, A. J. C., \& Glick, P. (2007). Universal dimensions of social cognition: Warmth and competence. Trends in Cognitive Sciences, 11(2), 77-83. https://doi.org/10.1016/j.tics.2006.11.005

Friend, S. (2016). Fiction and emotion. The Routledge Handbook of Philosophy of Imagination, 1978, 217-230. https://doi.org/10.4324/9781315657905

Georgiadis, J. R., \& Kringelbach, M. L. (2012). The human sexual response cycle: Brain imaging evidence linking sex to other pleasures. Progress in Neurobiology, 98(1), 49-81. https://doi.org/10.1016/j.pneurobio.2012.05.004

Gerrig, R. J. (1989). Suspense in the absence of uncertainty. Journal of Memory and Language, 28, 633-648.

Gerrig, R. J. (1998). Experiencing narrative worlds: On the psychological activities of reading. Westview Press. 
Gervais, M., \& Wilson, D. S. (2005). The evolution and functions of laughter and humor: A synthetic approach. The Quarterly Review of Baiology, 80(4), 395-430.

http://www.jstor.org/stable/10.1086/498281

Giles, D. C. . (2010). Parasocial relationships. Characters in Fictional Worlds: Understanding Imaginary Beings in Literature, Film, and Other Media, June, 442-457. https://doi.org/10.1515/9783110232424.4.442

Goetz, J. L., Keltner, D., \& Simon-Thomas, E. (2010). Compassion: An evolutionary analysis and empirical review. Psychological Bulletin, 136(3), 351-374. https://doi.org/10.1037/a0018807

Golovnev, A. V. (1997). Indigenous leadership in northwestern Siberia: Traditional patterns and their contemporary manifestations. Arctic Antbropology, 34(1), 149-166. https://doi.org/10.2307/40316430

Gopnik, A. (1998). Explanation as orgasm. Minds and Machines, 8(1), 101-118. https://doi.org/10.1023/A:1008290415597

Gottschall, J. (2005). The heroine with a thousand faces: Universal trends in the characterization of female folk tale protagonists. Evolutionary Psychology, 3(1), 147470490500300. https://doi.org/10.1177/147470490500300108

Gottschall, J. (2012). The storytelling animal: How stories make us human. Houghton Mifflin Harcourt.

Gottschall, J., \& Wilson, D. S. (Eds.). (2005). The literary animal: Evolution and the nature of narrative. Northwestern University Press.

Green, M. C., \& Brock, T. C. (2000). The role of transportation in the persuasiveness of public narratives. Journal of Personality and Social Psychology, 79(5), 701-721. https://doi.org/10.1037/0022-3514.79.5.701

Greitemeyer, T. (2010). Whom would you rather help: An acquaintance not responsible for her plight or a responsible sibling? The Journal of Social Psychology, 143(3), 331-340. https://doi.org/10.1080/00224540309598448

Hackel, L. M., Zaki, J., \& Van Bavel, J. J. (2017). Social identity shapes social valuation: Evidence from prosocial behavior and vicarious reward. Social Cognitive and Affective Neuroscience, 12(8), 1219-1228. https://doi.org/10.1093/scan/nsx045

Hard, R. (2004). The Routledge handbook of Greek mythology. Routledge.

Harry Potter Forums. (2011). Does anyone else miss the gang? Harry Potter Forums. https://www.potterforums.com/viewtopic.php?f=3\&t=46142

Henneberg, S. (2010). Moms do badly, but grandmas do worse: The nexus of sexism and ageism in children's classics. Journal of Aging Studies, 24(2), 125-134. https://doi.org/10.1016/j.jaging.2008.10.003

Hobbs, J. R. (1990). Literature and cognition. Center for the Study of Language and Information.

Hoffner, C. (1996). Children's wishful identification and parasocial interaction with favorite television characters. Journal of Broadcasting E Electronic Media, 40(3), 3-10.

Hoffner, C., \& Cantor, J. (1991). Perceiving and responding to mass media characters. In Responding to the screen: Reception and reaction processes (pp. 63-101). Lawrence Erlbaum Associates.

Hogan, P. C. (1996). Toward a cognitive science of poetics: Ānandavardhana, Abhinavagupta, and the theory of literature. College Literature, 23(1), 164-178.

http://www.jstor.org/stable/10.2307/25112235 
Hogan, P. C. (2003). The mind and its stories: Narrative universals and human emotion. Cambridge University Press.

Hogan, P. C. (2011). Affective narratology: The emotional structure of stories. University of Nebraska Press.

Hogan, P. C. (2017). The paradox of tragedy and emotional response to simulation. Behavioral and Brain Sciences, 40(e366), 31-32.

Iran-Nejad, A. (1987). Cognitive and affective causes of interest and liking. Journal of Educational Psychology, 79(2), 120-130. https://doi.org/10.1037/0022-0663.79.2.120

Jobling, I. (2001). The psychological foundations of the hero-ogre story. Human Nature, 12(3), 246-272.

Johnson, J. A., Carroll, J., Gottschall, J., \& Kruger, D. (2008). Hierarchy in the library: Egalitarian dynamics in Victorian novels. Evolutionary Psychology, 6(4), 715-738. https://doi.org/10.1177/147470490800600414

Jose, P. E. (1988). Liking of plan-based stories: The role of goal importance and goal attainment difficulty. Discourse Processes, 11(3), 261-273. https://doi.org/10.1080/01638538809544703

Jung, C. G. (1959). The archetypes and the collective unconscious. Bollingen Foundation.

Kanazawa, S. (2002). Bowling with our imaginary friends. Evolution and Human Behavior, 23(3), 167-171. https://doi.org/10.1016/S1090-5138(01)00098-8

Kao, K. S. (Ed.). (1985). Classical Chinese tales of the supernatural and the fantastic: Selections from the third to the tenth century. Indiana University Press.

Keen, S. (2007). Empathy and the novel. Oxford University Press.

Ker, A. (1910). Papuan fairy tales. Macmillan and Co.

Kimball, M. A. (1999). From folktales to fiction: Orphan characters in children's literature. Library Trends, 47(3), 558-578.

King, S. (2002). On writing. Simon and Schuster.

Klimmt, C., Hartmann, T., \& Schramm, H. (2006). Parasocial interactions and relationships. In J. Bryant \& P. Vorderer (Eds.), Psychology of Entertainment. Routledge.

Krakowiak, K. M., \& Oliver, M. B. (2012). When good characters do bad things: Examining the effect of moral ambiguity on enjoyment. Journal of Communication, 62(1), 117-135. https://doi.org/10.1111/j.1460-2466.2011.01618.x

Kringelbach, M. L. (2015). The pleasure of food: Underlying brain mechanisms of eating and other pleasures. Flavour, 4, 1-12. https://doi.org/10.1186/s13411-014-0029-2

Kringelbach, M. L., \& Berridge, K. C. (2009). Towards a functional neuroanatomy of pleasure and happiness. Trends in Cognitive Sciences, 13(11), 479-487. https://doi.org/10.1016/j.tics.2009.08.006

Kummer, H. (1978). On the value of social relationships to nonhuman primates: A heuristic scheme. Social Science Information, 17(4-5), 687-705. https://doi.org/10.1177/053901847801700418

Lévi-Strauss, C. (1955). The structural study of myth. The Journal of American Folklore, 68, 428455. http://www.jstor.org/stable/10.2307/536768

Light, S. N., Moran, Z. D., Swander, L., Le, V., Cage, B., Burghy, C., Westbrook, C., Greishar, L., \& Davidson, R. J. (2015). Electromyographically assessed empathic concern and empathic happiness predict increased prosocial behavior in adults. Biological Psychology, 104, 116-129. https://doi.org/10.1016/j.biopsycho.2014.11.015

Long, C. H. (2005). Cosmogony. In L. Jones (Ed.), Encyclopedia of Religion (2nd Editio, Vol. 3, 
pp. 1985-1991). Macmillan Reference.

Lwin, S. M. (2010). Narrative structures in Burmese folk tales. Cambria Press.

Lynn, M. (2009). Determinants and consequences of female attractiveness and sexiness: Realistic tests with restaurant waitresses. Archives of Sexual Behavior, 38(5), 737-745.

https://doi.org/10.1007/s10508-008-9379-0

Lynn, M., \& Simons, T. (2000). Predictors of male and female servers' average tip earnings. Journal of Applied Social Psychology, 30(2), 241-252. https://doi.org/10.1111/j.15591816.2000.tb02314.x

Maestripieri, D., Henry, A., \& Nickels, N. (2017). Explaining financial and prosocial biases in favor of the attractive people: Interdisciplinary perspectives from economics, social psychology, and evolutionary psychology. Behavioral and Brain Sciences, 40, e19, 1-16.

Mandler, J. M., \& Johnson, N. S. (1977). Remembrance of things parsed: Story structure and recall. Cognitive Psychology, 9(1), 111-151. https://doi.org/10.1016/0010-0285(77)90006-8

Mandler, J. M., Scribner, S., Cole, M., \& DeForest, M. (1980). Cross-cultural invariance in story recall. Child Development, 51(1), 19-26.

Mar, R. A. (2018). Evaluating whether stories can promote social cognition: Introducing the Social Processes and Content Entrained by Narrative (SPaCEN) framework. Discourse Processes, 55(5-6), 454-479. https://doi.org/10.1080/0163853X.2018.1448209

Mar, R. A., \& Oatley, K. (2008). The function of fiction is the abstraction and simulation of social experience. Perspectives on Psychological Science, 3(3), 173-192. https://doi.org/10.1111/j.1745-6924.2008.00073.x

Mar, R. A., Oatley, K., Djikic, M., \& Mullin, J. (2011). Emotion and narrative fiction: Interactive influences before, during, and after reading. Cognition E' Emotion, 25(5), 818833. https://doi.org/10.1080/02699931.2010.515151

Marshall, H. I. (1922). The Karen people of Burma: A study in anthropology and ethnology. The University of Ohio Press.

Martin, R. A. (2007). The psychology of humor: An integrative approach. Elsevier Inc.

Mattix, A. A. (2012). The orphan among us: An examination of orphans in Newbery Award winning literature [University of Pittsburgh]. http://www.dt.co.kr/contents.html?article_no=2012071302010531749001

McGraw, A. P., \& Warren, C. (2010). Benign violations: Making immoral behavior funny. Psychological Science, 21(8), 1141-1149. https://doi.org/10.1177/0956797610376073

Menninghaus, W., Wagner, V., Hanich, J., Wassiliwizky, E., Jacobsen, T., \& Koelsch, S. (2017). The Distancing-Embracing model of the enjoyment of negative emotions in art reception. Behavioral and Brain Sciences, 40, e347.

https://doi.org/10.1017/S0140525X17000309

Mesoudi, A., Whiten, A., \& Dunbar, R. (2006). A bias for social information in human cultural transmission. British Journal of Psychology, 97(3), 405-431. https://doi.org/10.1348/000712605X85871

Mobbs, D., Yu, R., Meyer, M., Passamonti, L., Seymour, B., Calder, A. J., Schweizer, S., Frith, C. D., \& Dalgleish, T. (2009). A key role for similarity in vicarious reward. Science, 324, 900. https://doi.org/10.1126/science.1170539

Morelli, S. A., Lieberman, M. D., \& Zaki, J. (2015). The emerging study of positive empathy. Social and Personality Psychology Compass, 9(2), 57-68. https://doi.org/10.1111/spc3.12157

Morin, O., Acerbi, A., \& Sobchuk, O. (2019). Why people die in novels: testing the ordeal 
simulation hypothesis. Palgrave Communications, 5(1), 1-10.

https://doi.org/10.1057/s41599-019-0267-0

Nettle, D. (2005). What happens in Hamlet? Exploring the psychological foundations of drama. In J. Gottschall \& D. S. Wilson (Eds.), The literary animal: Evolution and the nature of narrative (pp. 56-75). Northwestern University Press.

Oatley, K. (1999). Why fiction may be twice as true as fact: Fiction as cognitive and emotional simulation. Review of General Psychology, 3(2), 101-117.

Oatley, K. (2008). The mind's flight simulator. The Psychologist, 21(12), 1030-1033.

Oatley, K. (2011). Such stuff as dreams: The psychology of fiction. Wiley-Blackwell. https://doi.org/10.1002/9781119970910

Oatley, K. (2016). Fiction: Simulation of social worlds. Trends in Cognitive Sciences, 20(8), 618628. https://doi.org/10.1016/j.tics.2016.06.002

Oatley, K., \& Mar, R. (2005). Evolutionary pre-adaptation and the idea of character in fiction. Journal of Cultural and Evolutionary Psychology, 3, 179-194. https://doi.org/10.1556/JCEP.3.2005.2.5

Ohnuki-Tierney, E. (1974). The Ainu of the northwest coast of southern Sakbalin. Holt, Rinehart, and Winston, Inc.

Olcott, F. J. (1917). The Red Indian fairy book: For the children's own reading and for story-tellers. Houghton Mifflin Company.

Oliver, M. B., \& Bartsch, A. (2010). Appreciation as audience response: Exploring entertainment gratifications beyond hedonism. Human Communication Research, 36(1), 5381. https://doi.org/10.1111/j.1468-2958.2009.01368.x

Oliver, M. B., \& Raney, A. A. (2011). Entertainment as pleasurable and meaningful: Identifying hedonic and eudaimonic motivations for entertainment consumption. Journal of Communication, 61(5), 984-1004. https://doi.org/10.1111/j.1460-2466.2011.01585.x

Owens, J., Bower, G. H., \& Black, J. B. (1979). The "soap opera" effect in story recall. Memory E Cognition, 7(3), 185-191. https://doi.org/10.3758/BF03197537

Perrault, C. (1697). Histoires ou contes du temps passé. Claude Barbin. https://fr.wikisource.org/wiki/Histoires_ou_Contes_du_temps_passé_(1697)/Original

Petrovitch, W. M. (1915). Hero tales and legends of the Serbians. Frederick A. Stokes Company. https://archive.org/details/herotaleslegends00petrrich/page/n9

Pinker, S. (1997). How the mind works. W. W. Norton \& Company.

Pinker, S. (2007). Toward a consilient study of literature. Philosophy and Literature, 31(1), 162178. https://doi.org/10.1353/phl.2007.0016

Pisor, A. C., \& Gurven, M. (2016). Risk buffering and resource access shape valuation of outgroup strangers. Scientific Reports, 6, 1-10. https://doi.org/10.1038/srep30435

Pisor, A. C., \& Gurven, M. (2018). When to diversify, and with whom? Choosing partners among out-group strangers in lowland Bolivia. Evolution and Human Behavior, 39(1), 3039. https://doi.org/10.1016/j.evolhumbehav.2017.09.003

Pittinsky, T. L., \& Montoya, R. M. (2016). Empathic joy in positive intergroup relations. Journal of Social Issues, 72(3), 511-523. https://doi.org/10.1111/josi.12179

Propp, V. (1968). Morphology of the folktale. University of Texas Press.

Radford, C., \& Weston, M. (1975). How can we be moved by the fate of Anna Karenina? Proceedings of the Aristotelian Society, Supplementary Volumes, 49, 67-93.

Radin, P. (1915). Literary aspects of North American mythology. Government Printing Office. 
Radin, P. (1956). The trickster: A study in American Indian mythology. Philosophical Library.

Rafe, M. (1992). The rough-face girl. G. P. Putnam's Sons.

Raglan, F. R. S. (1936). The hero: A study in tradition, myth, and drama. Watts \& Co.

Raihani, N. J., \& Smith, S. (2015). Competitive helping in online giving. Current Biology, 25(9), 1183-1186. https://doi.org/10.1016/j.cub.2015.02.042

Raney, A. A. (2003). Disposition-based theories of enjoyment. In J. Bryant, D. RoskosEwoldsen, \& J. Cantor (Eds.), Communication and emotion: Essays in honor of Dolf Zillmann (pp. 61-84). Lawrence Erlbaum Associates.

Rank, O. (1914). The myth of the birth of the hero: A psychological interpretation of mythology. The Journal of Nervous and Mental Disease Publishing Company.

Rongmuthu, D. S. (1960). The folk-tales of the Garos. University of Gauhati, Department of Publications.

Royzman, E. B., \& Rozin, P. (2006). Limits of symhedonia: The differential role of prior emotional attachment in sympathy and sympathetic joy. Emotion, 6(1), 82-93. https://doi.org/10.1037/1528-3542.6.1.82

Rozin, P. (1999). Preadaptation and the puzzles and properties of pleasure. In D. Kahneman, E. Diener, \& N. Schwartz (Eds.), Well being: The foundations of hedonic psychology (pp. 109133). Russell Sage.

Rozin, P., Markwith, M., \& Ross, B. (1990). The sympathetic magical law of similarity, nominal realism and neglect of negatives in response to negative labels. Psychological Science, 1(6), 383-384. https://doi.org/10.1111/j.1467-9280.1990.tb00246.x

Rozin, P., Millman, L., \& Nemeroff, C. (1986). Operation of the laws of sympathetic magic in disgust and other domains. Journal of Personality and Social Psychology, 50(4), 703-712.

Rubin, R. B., \& McHugh, M. P. (1987). Development of parasocial interaction relationships. Journal of Broadcasting E Electronic Media, 31(3), 279-292. https://doi.org/10.1080/08838158709386664

Rudolph, U., Roesch, S. C., Greitemeyer, T., \& Weiner, B. (2004). A meta-analytic review of help giving and aggression from an attributional perspective: Contributions to a general theory of motivation. Cognition and Emotion, 18(6), 815-848. https://doi.org/10.1080/02699930341000248

Samuels, A., \& Taylor, M. (1994). Children's ability to distinguish fantasy events from real-life events. British Journal of Developmental Psychology, 12(4), 417-427. https://doi.org/10.1111/j.2044-835x.1994.tb00644.x

San Souci, R. D. (1994). Sootface: An Ojibwa Cinderella Story. Doubleday.

Scalise Sugiyama, M. (2001). Food, foragers, and folklore: The role of narrative in human subsistence. Evolution and Human Behavior, 22(4), 221-240.

https://doi.org/10.1016/S1090-5138(01)00063-0

Scheub, H. (1975). The Xhosa ntsomi. Clarendon Press.

Scheub, H. (2007). Trickster and hero: Two characters in the oral and written traditions of the world. The University of Wisconsin Press.

Shen, W., Yuan, Y., Liu, C., \& Luo, J. (2016). In search of the “Aha!" experience: Elucidating the emotionality of insight problem-solving. British Journal of Psychology, 107(2), 281-298. https://doi.org/10.1111/bjop.12142

Singh, M. (2020). Subjective selection and the evolution of complex culture. PsyArxiv. https://doi.org/10.31234/osf.io/4t2ud 
Singhal, A., Obregon, R., \& Rogers, E. M. (1994). Reconstructing the story of Simplemente María, the most popular telenovela in Latin America of all time. Gazette, 54, 1-15.

Skolnick, D., \& Bloom, P. (2006). What does Batman think about SpongeBob? Children's understanding of the fantasy/fantasy distinction. Cognition, 101(1), 9-18. https://doi.org/10.1016/j.cognition.2005.10.001

Smith, K. D., Keating, J. P., \& Stotland, E. (1989). Altruism reconsidered: The effect of denying feedback on a victim's status to empathic witness. Journal of Personality and Social Psychology, 57(4), 641-650. https://doi.org/10.1037/0022-3514.57.4.641

Sood, S., \& Rogers, E. M. (2000). Dimensions of parasocial interaction by letter-writers to a popular entertainment-education soap opera in India. Journal of Broadcasting E Electronic Media, 44(3), 386-414. https://doi.org/10.1207/s15506878jobem4403

Steen, F. F., \& Owens, S. A. (2001). Evolution's pedagogy: An adaptationist model of pretense and entertainment. Journal of Cognition and Culture, 1(4), 289-321. https://doi.org/10.1163/156853701753678305

Stubbersfield, J. M., Tehrani, J. J., \& Flynn, E. G. (2015). Serial killers, spiders and cybersex: Social and survival information bias in the transmission of urban legends. British Journal of Psychology, 106(2), 288-307. https://doi.org/10.1111/bjop.12073

Sutton-Smith, B. (1981). The folkstories of children. University of Pennsylvania Press.

Tan, E. S. (1996). Emotion and the structure of narrative film: Film as an emotion machine. Lawrence Erlbaum Associates.

Telle, N.-T., \& Pfister, H.-R. (2016). Positive empathy and prosocial behavior: A neglected link. Emotion Review, 8(2), 154-163. https://doi.org/10.1177/1754073915586817

Telzer, E. H., Masten, C. L., Berkman, E. T., Lieberman, M. D., Fuligni, A. J., Telzer, E. H., Masten, C. L., Berkman, E. T., Matthew, D., Telzer, E. H., Masten, C. L., Berkman, E. T., Lieberman, M. D., \& Fuligni, A. J. (2010). Gaining while giving: An fMRI study of the rewards of family assistance among White and Latino youth. Social Neuroscience, 5(5-6), 508-518. https://doi.org/10.1080/17470911003687913

Thompson, S. (1946). The folktale. The Dryden Press. https://catalog.hathitrust.org/Record/001276234

Thorndyke, P. W. (1977). Cognitive structures in comprehension and memory of narrative discourse. Cognitive Psychology, 9(1), 77-110. https://doi.org/10.1016/00100285(77)90005-6

Tooby, J., \& Cosmides, L. (1996). Friendship and the banker's paradox: Other pathways to the evolution of adaptations for altruism. Proceedings of the British Academy, 88, 119-143. https://doi.org/10.1002/(SICI)1520-6300(1998)10:5<681::AID-AJHB16>3.3.CO;2-I

Tooby, J., \& Cosmides, L. (2001). Does beauty build adapted minds? Toward an evolutionary theory of aesthetics, fiction and the arts. SubStance, 30, 6-27. https://doi.org/10.1353/sub.2001.0017

Topolinski, S., \& Reber, R. (2010). Gaining insight into the "Aha” experience. Current Directions in Psychological Science, 19(6), 402-405. https://doi.org/10.1177/0963721410388803

Trabasso, T., \& Chung, J. (2004). Empathy: Tracking characters and monitoring their concerns in film. Winter Text Conference, Jackson Hole, WY.

Trabasso, T., \& Sperry, L. (1985). Causal relatedness and importance of story events. Journal of Memory and Language, 24, 595-611. 
Trabasso, T., \& van den Broek, P. (1985). Causal thinking and the representation of narrative events. Journal of Memory and Language, 24(5), 612-630. https://doi.org/10.1016/0749596X(85)90049-X

Trivers, R. (1971). The evolution of reciprocal altruism. Quarterly Review of Biology, 46, 35-57. http://www.jstor.org/stable/10.2307/2822435

TV Tropes. (2019a). Death by childbirth. TV Tropes. https://tvtropes.org/pmwiki/pmwiki.php/Main/DeathByChildbirth

TV Tropes. (2019b). Orphaned index. TV Tropes. https://tvtropes.org/pmwiki/pmwiki.php/Main/OrphanedIndex

von Hahn, J. G. (1876). Sagwissenschaftliche studien. Friedrich Mauke.

Vorderer, P., Klimmt, C., \& Ritterfield, U. (2004). Enjoyment: At the heart of media entertainment. Communication Theory, 14(4), 388-408. https://doi.org/10.1111/j.14682885.2004.tb00321.x

Wallace, J. (2013). Tragedy in China. Cambridge Quarterly, 42(2), 99-111. https://doi.org/10.1093/camqtly/bft017

Weber, R., Tamborini, R., Lee, H. E., \& Stipp, H. (2008). Soap opera exposure and enjoyment: A longitudinal test of disposition theory. Media Psychology, 11(4), 462-487. https://doi.org/10.1080/15213260802509993

West, S. A., Griffin, A. S., \& Gardner, A. (2007). Social semantics: altruism, cooperation, mutualism, strong reciprocity and group selection. Journal of Evolutionary Biology, 20(2), 415-432. https://doi.org/10.1111/j.1420-9101.2006.01258.x

Whitehouse, W. (1935). Ochikubo Monogatari or the tale of the Lady Ochikubo: A tenth century Japanese novel. Kegal Paul, Trench, Trubner \& Co.

Winsey, V. (1979). How soaps help you cope. Family Health, 11(4), 30-33.

Witzel, M. (2012). The origin of the world's mythologies. Oxford University Press.

Woolley, J. D., \& Phelps, K. E. (1994). Young children's practical reasoning about imagination. British Journal of Developmental Psychology, 12(1), 53-67. https://doi.org/10.1111/j.2044835x.1994.tb00618.x

Zacks, J. M., Speer, N. K., Swallow, K. M., Braver, T. S., \& Reynolds, J. R. (2007). Event perception: A mind-brain perspective. Psychological Bulletin, 133(2), 273-293. https://doi.org/10.1037/0033-2909.133.2.273

Zillmann, D. (1995). Mechanisms of emotional involvement with drama. Poetics, 23(1-2), 3351. https://doi.org/10.1016/0304-422X(94)00020-7

Zillmann, D., \& Cantor, J. R. (1977). Affective responses to the emotions of a protagonist. Journal of Experimental Social Psychology, 13(2), 155-165. https://doi.org/10.1016/S00221031(77)80008-5

Zillmann, D., Taylor, K., \& Lewis, K. (1998). News as nonfiction theater: How dispositions toward the public cast of characters affect reactions. Journal of Broadcasting and Electronic Media, 42(2), 153-169. https://doi.org/10.1080/08838159809364441

Zillmann, D., \& Vorderer, P. (2000). Media entertainment: The psychology of its appeal.

Zunshine, L. (2006). Why we read fiction: Theory of mind and the novel. The Ohio State University Press. 